\title{
PENGARUH PERMAINAN BOLA KERANJANG TERHADAP KEMAMPUAN MOTORIK KASAR ANAK KELOMPOK B (5-6 TAHUN) DI TK AISYIYAH 11 PALEMBANG
}

\author{
Elen', Dr. H. Bukman Lian, MM.,M.Si' ${ }^{2}$ Rahmah Novianti, S.Sos.,M.Pd ${ }^{3}$ \\ Email : elene8636@gmail.com ${ }^{1}$,drbukmanlian@gmail.com², \\ aliciarahmah@gmail.com ${ }^{3}$
}

\begin{abstract}
Abstrak : Penelitian ini bertujuan untuk mengetahui ada atau tidaknya pengaruh permainan bola keranjang terhadap kemampuan motorik kasar anak kelompok B (5-6 tahun) di TK aisyiyah 11 Palembang. Dalam penelitian ini menggunakan penelitian kuantitatif dengan metode eksperimen, design yang digunakan dalam penelitian ini adalah One-Groub-Pretest-Posttest Design. Sampel yang digunakan dalam penelitian ini yaitu seluruh anak kelompok B2 TK Aisyiyah 11 Palembang yang berjumlah 17 anak. Teknik pengumpulan data yang digunakan yaitu melakukan observasi dan dokumentasi, dan untuk analisis data menggunakan Uji-t. Berdasarkan hasil penelitian pretest dan posttestyang dihitung menggunakan uji-t dengan taraf signifikan $(\alpha) 0,05$ dan dan $\mathrm{dk}=17-1$ $=16$ di dapatkan nilai $t_{\text {hitung }}=6,20$ dengan demikian dapat disimpulkan bahwa $t_{\text {hitung }}>t_{\text {tabel }}$ atau $(6,20>1,746)$ maka $\mathrm{H}_{0}$ ditilak dan $\mathrm{H}_{\mathrm{a}}$ diterima. Dengan demikian kegiatan permainan bola keranjang memiliki pengaruh yang signifikan terhadap kemampuan motorik kasar anak kelompok B2 (5-6 tahun) di TK Aisyiyah 11 Palembang.
\end{abstract}

Kata kunci : Permainan Bola Keranjang, Motorik Kasar

\section{PENDAHULUAN}

Pendidikan anak usia dini merupakan suatu upaya pembinaan yang ditujukan anak sejak lahir sampai dengan usia enam tahun yang dilakukan melalui pemberian rangsangan pendidikan untuk membantu pertumbuhan dan perkembangan anak. Dalam pendidikan anak usia dini anak lebih senang bermain ketimbang belajar. Maka dari itu proses pembelajaran anak usia dini itu lebih menekankan bermain seraya belajar atau belajar sambil bermain. Hal ini bertujuan agar pembelajaran yang diberikan lebih bermakna bagi anak sehingga potensi yang dimiliki anak dapat berkembang secara optimal.

Anak usia dini memiliki karakteristik yang khas dan tidak sama dengan orang dewasa, mereka selalu aktif, dinamis, antusias dan ingin tahu terhadap apa yang dilihat, didengar, dan dirasakan mereka seolah-olah tidak pernah berhenti bereksplorasi dan belajar.

Berdasarkan hal tersebut bahwa pendidikan anak usia dini sangatlah penting, karena anak usia dini merupakan usia yang sangat kritis dimana pada usia tersebut 
merupakan dasar untuk tahap perkembangan selanjutnya. Oleh sebab itu maka guru dan orang tua perlu memahami betapa pentingnya pendidikan anak usia dini dalam mengembangkan 6 aspek perkembangan anak, nilai agama dan moral, fisik motorik, kognitif, sosial emosional, bahasa dan seni.

Salah satu aspek yang harus dikembangkan pada anak usia dini adalah aspek perkembangan motorik kasar anak karena perkembangan motorik kasar ini sangat berpengaruh terhadap keseimbangan anak, dan memasuki pendidikan selanjutnya, agar memiliki kesiapan untuk menggunakan otot-otot besar dengan tepat dan benar.

Motorik kasar merupakan gerakan-gerakan yang dilakukan anak yang dapat melatih otot-otot besar agar menjadi lebih kuat dan terlatih. Gerakan motorik kasar ini bertujuan untuk menstimulasi perkembangan otot, sebagai modal dasar memudahkan anak dalam bergerak atau tidak kaku dan lincah. Melatih kemampuan motorik kasar dapat menggunakan berbagai macam

kegiatan salah satunya yakni kegiatan permainan bola keranjang.

Kegiatan permainan bola keranjang merupakan salah satu permainan yang menggunakan otototot besar untuk melempar bola kedalam keranjang. Selain menyehatkan tubuh permainan bola keranjang ini juga dapat membuat hubungan kerjasama yang erat antar pemainnya. Permainan bola keranjang sangat memberikan efek yang sangat baik salah satunya adalah untuk melatih otot kaki dan tangan. Selain itu pula, bila seorang anak tubuhnya sehat, kuat, cekatan melakukan gerakan-gerakan, baik berlari, bergelantungan, melompat, menendang, melempar, serta menangkap bola, maka ia lebih siap menekuni bidang olahraga tertentu pada usia yang lebih besar

$\begin{array}{lrr}\text { Permainan } & \text { bola } & \text { keranjang } \\ \text { ditujukan } & \text { untuk } & \text { lebih } \\ \text { mengembangkan } & \text { kemampuan } \\ \text { motorik kasar pada anak. Aturannya } \\ \text { pun sangat berbeda dengan } \\ \text { permainan bola keranjang bagi orang } \\ \text { dewasa. Bagi anak-anak aturan } \\ \text { permainan ini yaitu bagaimana agar } \\ \text { anak mampu menangkap dan } \\ \text { melempar bola, dan memasukkannya }\end{array}$


ke dalam keranjang yang tentunya disesuaikan dengan tinggi anak.

Berdasarkan hasil penelitian yang telah dilakukan Frida Citra Cuacicha (2016) Universitas Lampung, dalam penelitian yang berjudul "Pengaruh Bermain Lempar Tangkap Bola Terhadap Motorik Kasar Anak Kelompok B DI TK Pertiwi Sumberrejo Kotagajah Lampung Tengah" diketahui bahwa bermain lempar tangkap bola dapat berpengaruh terhadap motorik kasar anak karena pada saat bermain anak memanfaatkan kekuatan otot tangan yang meliputi lempar bola, menangkap bola dan melambungkan bola. Kegiatan bermain lempartangkap bola juga memanfaatkan kekuatan otot kaki untuk menyeimbangkan badan saat melempar, menangkap bola dan berlari zig-zag.

\footnotetext{
Permainan bola keranjang ditujukan untuk lebih mengembangkan kemampuan motorik kasar pada anak. Aturannya pun sangat berbeda dengan permainan bola keranjang bagi orang dewasa. Bagi anak-anak aturan
}

permainan ini yaitu bagaimana agar anak mampu menangkap dan melempar bola, dan memasukkannya ke dalam keranjang yang tentunya disesuaikan dengan tinggi anak.

Berdasarkan identifikasi dan pembatasan masalah maka rumusan masalah dalam penelitian ini adalah Adakah Pengeruh Permainan Bola Keranjang Terhadap Kemampuan Motorik Kasar Anak Kelompok B (5-6 Tahun) Di TK Aisyiyah 11 Palembang?

Penelitian ini bertujuan untuk mengetahui ada atau tidak Pengaruh Permainan Bola Keranjang Terhadap Kemampuan Motorik Kasar Anak Kelompok B (5-6 Tahun) di TK Aisyiyah 11 Palembang.

\section{KAJIAN TEORI}

Permainan secara umum adalah suatu aktivitas untuk meningkatkan keterampilan dan perkembangan anak, Menurut Desmita (2015, hal.141) permainan adalah salah satu bentuk aktivitas sosial yang dominan pada awal masa anak-anak. Sebab, anak-anak menghabiskan lebih banyak waktunya di luar rumah bermain dengan teman-temannya 
dibanding terlibat dalam aktivitas lainnya.

Selanjutnya Menurut Santrock dalam (Euis Kurniati, 2016) menjelaskan bahwa permainan (play) ialah suatu kegiatan yang menyenangkan yang dilaksanakan untuk kepentingan kegiatan itu sendiri. Permainan merupakan suatu aktifitas bermain yang didalamnya telah memiliki aturan yang jelas dan disepakati bersama

Sedangkan Menurut Suyadi (2015, hal.34) permainan adalah sesuatu yang menyenangkan, suka rela, penuh arti, dan aktivitas spontan. permainan sering juga diangap kreatif, yang menyertakan pemecahan masalah belajar keterampilan sosial baru, bahasa dan keterampilan fisik yang baru.

Berdasarkan pendapat diatas dapat ditarik kesimpulan bahwa permainan adalah suatu aktivitas yang sangat menyenangkan, suka rela, penuh arti, dan sangat membantu anak dalam mengembangkan aktivitasnya sehingga anak akan lebih senang menghabiskan waktunya diluar rumah untuk bermain.
Adapun manfaat permainan bagi anak khususnya anak usia dini di antaranya:

1) Aspek Fisik, yaitu anak berkesempatan melakukan kegiatan yang melibatkan gerakan-gerakan tubuh yang membuat tubuh anak sehat dan otot-otot tubuh menjadi kuat, sehingga akan meransang kecerdasan bodly kinestetic-nya baik dalam bentuk motorik kasar ataupun motorik kasar.

2) Aspek Sosial Emosional, yaitu anak merasa senang karena ada teman bermainnya. Di tahuntahun pertama kehidupan, orang tua merupakan teman bermain yang utama bagi anak.

3) Mengasah Ketajaman Pengindraan, yaitu pengindraan anak perlu di asah agar anak menjadi lebih peka terhadap halhal yang terjadi di lingkungannya.

4) Media Terapi, yaitu bermain dapat digunakan sebagai media terapi karena selama bermain perilaku anak lebih bebas.

Menurut Suyanto (dalam Susanto, 2017, hal 106) jenis 
permainan dapat di kelompokan menjadi lima yaitu sebagai berikut:

1) Permainan fisik, yaitu permainan yang banyak menggunakan kegiatan fisik, seperti bermain kejar-kejaran.

2) Bermain teka-teki dan berfikir logis matematis, yaitu permainan yang tujuannya mengembangkan kemampuan yang berfikir logis dan matematis.

3) Bermain dengan benda-benda, yaitu bermain dengan objek seperti air, pasir, dan balok yang dapat mengembangkan berbagai aspek perkembangan.

Menurut Fadlillah (2014, hal. 38) menjelaskan faktor yang mempengaruhi permainan anak, di antaranya:

1) Kesehatan, yaitu semakin sehat anak semakin banyak energinya untuk bermain aktif, seperti olahraga. Adapun anak yang kurang tenaga (tidak sehat) lebih menyukai hiburan.

2) Perkembangan Motorik, yaitu permainan anak pada setiap usia melibatkan koordinasi motorik.
3) Jenis Kelamin, yaitu anak lakilaki bermain lebih kasar di bandingkan anak perempuan.

4) Lingkungan, yaitu lingkungan yang kurang mendukung akan dapat memengaruhi anak dalam bermain. Lingkungan yang sepi dari anak-anak akan kurang rasa bermainnya dibandingkan dengan lingkungan tang terdapat banyak anak.

5) Peralatan Bermain, yaitu peralatan bermain yang dimiliki anak memengaruhi permainnanya. Misalnya, dominasi boneka atau kartun lebih mendukung pada permainan pura-pura.

Menurut Teguh Sutanto (2017, ha;.42) bola keranjang adalah olahraga bola berkelompok yang terdiri atas dua tim beranggotakan masing-masing lima orang yang saling bertanding mencetak poin dengan memasukan bola kedalam keranjang lawan. Olahraga ini bisa dimainkan diruang olahraga tertutup dan hanya memerlukan lapangan yang relatif kecil.

Selanjutnya menurut Atmasubrata (2012, hal.44) bola 
keranjang adalah olahraga bola berkelompok yang terdiri dari dua tim yang beranggotakan masingmasing lima orang. Mereka saling bertanding mencetak poin dengan memasukan bola kedalam keranjang kawan.

Sedangkan Menurut Rahmani (2016, hal.50) olahraga bola keranjang merupakan olahraga yang menggunakan bola dan dimainkan secara beregu. Tiap regunya terdiri dari 5 orang. Olahraga ini pada umumnya dimainkan dalam ruangan tertutup atau indoor. Berbeda dengan yang terjadi disekolah, dimana olahraga bola keranjang lebih banyak dimainkan di ruangan terbuka.

Berdasarkan pendapat diatas dapat disimpulkan bahwa bola keranjang adalah olahraga yang terdiri dari dua tim yang bertujuan untuk mencetak poin olahraga ini terdiri dari 5 orang dalam satu tim, permainan ini bisa dimainkan dilapangan atau di lapangan sekolah dan luas lapangannya disesuaikan dengan anak usia dini.

Sutanto (2016, hal.50) menyebutkan teknik dasar permainan bola keranjang: 1) cara memegang bola, 2) mengopor, 3) mengiring bola, 4) shooting 5) lay-up

1) Cara menangkap bola, sikap tangan membentuk mangkok besar. Bola berada di antara kedua telapak tangan. Telapak tangan melekat di samping bola agak kebelakang, jari-jari rentang melekat pada bola.

2) Mengopor atau melempar bola, melempar bola dari atas kepala, melempar dari depan dada yang dilakukan dari dada ke dada dengan cepat dalam permainan, serta melempar bola memantul ke tanah atau lantai.

3) Mengiring bola, suatu usaha membawa bola kedepan. Caranya yaitu dengan memantul-mantulkan bola kelantai dengan satu tangan.saat bola bergerak keatas telapak tangan menempel pada bola yang mengikuti arah bola.

4) Shooting, suatu usaha memasukan bola kedalam keranjang lawan untuk meraih poin. Ini dapat dilakukan dengan cara yaitu dengan shooting dengan dua tangan serta shooting dengan satu tangan. 
Kemampuan merupakan suatu bakat yang dimiliki seseorang untuk melakukan kegiatan secara fisik atau mental yang diperoleh dari sejak lahir.

Menurut Sudiro (2018, hal.3) kemampuan adalah sebuah penilaian saat ini atas apa yang di lakukan seseorang.

Menurut Pratiwi (2014, hal.21) kemampuan adalah keseluruhan potensi yang dimiliki seseorang yang menyelesaikan tugasnya dengan baik mengenai tugas fisik dan mentalnya. Suatu potensi yang dimiliki anak guna untuk menyelesaikan tugas dengan baik sesuai fisik dan mentalnya.

Sedangkan menurut Sinaga, dkk (dalam Astute, 2015, hal 71) mendefinisikan kemampuan sebagai suatu dasar seseorang yang dengan sendirinya berkaitan dengan pelaksanaan pekerjaan secera efektif atau sangat berhasil.

Dari hasil uraian di atas dapat di simpulkan kemampuan adalah suatu potensi yang dimiliki oleh seseorang guna untuk meningkatkan fisik atau mental dalam bidang pekerjaan

Menurut Badeni (dalam pratiwi, 2014, hal.21) menyatakan bahwa ada 2 jenis kemampuan yaitu sebagai berikut:

1) Kemampuan intelektual adalah kemampuan yang diperlukan untuk melaksanakan aktofitasaktifitas mental. Contohnya tes IQ (Intelligent quotient) guna untuk menegaskan seberapa tingkat kemampuankemampuan intelektual umum.

2) Kemampuan fisik adalah kemampuan intelektual lebih besar dalam memainkan peran pada pekerjaan yang rumit sebagai persyaratan dalam proses informasi sementara kemampuan fisik lebih banyak dibutuhkan dari pada aktivitas atau tugas yg menuntut stamina.

Motorik kasar merupakan suatu aspek perkembangan yang melibatkan otot-otot besar atau gerakan tangan seperti melempar dan menagkap bola. 
Menurut Rahyubi (2016, hal.222) motorik kasar adalah keterampilan gerak atau gerakan tubuh yang memakai otot-otot besar sebagai dasar utama gerakannya. Motorik kasar meliputi pola lokomotor (gerak yang menyebabkan perpindahan tempat) seperti berjalan, berlari, melompat, meloncat, dan sebagainya. Juga keterampilan menguasai bola seperti melempar, menendang, dan memantulkan bola.

Selanjutnya Menurut Marsid (2016, hal.12) motorik kasar adalah melatih gerak jasmani berupa koordinasi gerakan tubuh pada anak, seperti merangkak, berlari, berjinjit, melompat bergantung, melempar dan menangkap, serta menjaga keseimbangan.

Sedangkan menurut Suryana (2018. Hal,153) motorik kasar adalah gerak tubuh yang menggunakan otototot besar atau sebagian besar atau seluruh anggota tubuh yang dipengaruhi oleh kematangan kita sendiri, contohnya kemampuan duduk, menendang, berlari, dan naik turun tangga.

Dari hasil uraian diatas bahwa kemampuan motorik kasar adalah potensi yang dimiliki oleh seseorang untuk meningkatkan fisik ataupun mental menggunakan otot-otot besar tubuhyang mencakup gerakan kaki dan tangan, dalam melakukan berbagai kegiatanseperti gerakan kaki, berjalan, berlari, melompat, meloncat, otot-otot tangan melempar dan menangkap bola.

Dengan demikian permainan bola keranjang dapat dimaknai dengan permainan yang sangat menyenangkan bagi anak usia dini.

Menurut Cuacicha (dalam depdiknas, 2016, hal,15-16) Ada banyak manfaat bagi anak untuk mengembangkan kemampuan motorik kasar sebagai berikut:

1) Melatih kelenturan dan koordinasi otot jari dan tangan

2) Memacu perkembangan dan pertumbuhan fisik/motorik, rohani dan kesehatan anak.

3) Membentuk, membangun dan memperkuat tubuh anak.

4) Melatih keterampilan/ketangkasan gerak dan berfikir anak 
Menurut Rahyubi (2012, hal.225) mengemukakan ada beberapa faktor yang mempengaruhi perkembangan motorik anak, antara lain adalah:

1) Perkembangan sistem syaraf yaitu sistem syaraf sangat berpengaruh dalam perkembangan motorik, karenasistem syaraflah yang mengontrol aktivitas motorik pada tubuhmanusia.

2) Kondisi fisik yaitu perkembangan motorik erat kaitannya dengan fisik, maka kondisi fisiktentu saja sangat berpengaruh pada perkembangan motorik seseorang.Seseorang yang normal biasanya perkembangan motoriknya akan lebihbaik dibandingkan orang lain yang memiliki kekurangan fisik.

3) Motivasi yang kuat yaitu seseorang yang mempunyai motovasi kuat unuk menguasaiketerampilan

motoriknya tertentu biasanya telah punya modal besaruntuk meraih prestasi. Apabila seseorang mampu melakukan suatuaktivitas motorik dengan baik, maka kemungkinan besar dia akantermotivasi untuk menguasai keterampilan motorik yang lebih luas.

4) Lingkungan yang kondusif yaitu perkembangan motorik seorang individu kemungkinan besar bisaberjalan optimal jika lingkungan tempatnya beraktivitas mendukungdan kondusif. Lingkungan dalam hal ini bisa berarti fasilitas, peralatan,sarana dan prasarana.

Beberapa penelitian terdahulu yang relevan dengan penelitian ini diantaranya adalah sebagai berikut:

Berdasarkan penelitian yang dilakukan oleh Evritasari (2019) Universitas Negeri Surabaya, yang berjudul "Pengaruh Permainan Bola Basket Modifikasi Terhadap Kemampuan Motorik Kasar Anak TK $B$ "mengalami perkembangan setelah perlakuan (treatmen). Skor total yang didapatkan oleh 14 anak pada pretest sebesar 40 dengan skor rata-rata sebesar 2,85. Pada kegiatan posttest skor total yang didapatkan 14 anak sebesar 67 dengan skor rata-rata sebesar 4,78. Hasil perhitungan dengan uji wilcoxsonmath pairs test 
menunjukan perolehan Thitung > Ttabel $=(0>8)$ maka hipotesis nol (Ho) ditolak dan hipotesis kerja (Ha) diterima. Dengan demikian dapat disimpulkan bahwa penggunaan permainan bola basket modifikasi berpengaruh terhadap kemapuan motorik kasar anak. Peningkatan kemampuan motorik kasar tersebut terjadi karena kegiatan dilakukan secara berulang-ulang dan anak sudah mulai mengenal konsep bagaimana cara dribel dan shooting yang sebelumnya belum pernah mereka kerjakan.

Selanjutnya penelitian yang dilakukan oleh Wati (2012) yang berjudul "Pengaruh Permainan Modifikasi Bola Basket Terhadap Kemampuan Motorik Kasar Anak Di Kelompok B2 Tk Al-Khairaat Iii Palu" dapat disimpulkan bahwa ada pengaruh modifikasi permainan bola basket terhadap kemampuan motorik kasar anak. Hal ini dapat dilihat dari sebelum dan sesudah diberikan modifikasi permainan bola basket yang berunsurkan permainan, seperti Menangkap Bola, Mendribbling Bola, dan Memasukkan Bola kedalam Ring, terjadi peningkatan kemampuan motorik kasar anak pada setiap kategori Berkembang Sangat Baik (BSB) untuk masing-masing aspek yang diamati.

Berdasarkan dua penelitian tersebut, persamaan dari penelitiaan ini dengan yang akan diteliti yaitu pada variabel Y yaitu kemampuan motorik kasar anak dan pada variabel $\mathrm{X}$ yaitu kegiatan permainan bola keranjang dan jenis penelitian. Sedangkan perbedaan terletak pada subjek, tempat dan waktu penelitiannya dilaksanakan.

\section{METODOLOGI PENELITIAN}

Dalam desain ini penelitian yang digunakan pada penelitian ini adalah One-group Pretest-posttest Design. Pada desain ini terdapat Pretest sebelum diberi perlakuan, sehingga hasil perlakuan dapat diketahui lebih akurat, karena dapat membandingkan dengan keadaan sebelum diberi perlakuan. Desain ini dapat digambarkan sebagai berikut:

\section{Gambar 3.3. One -Group Pretest- Posttest Design}

$\mathrm{O}_{1} \times \mathrm{O}_{2}$ 
Keterangan :

$\mathrm{O}_{1}=$ Nilai Pretest (sebelum diberi perlakuan)

$\mathrm{O}_{2}=$ Nilai Posttest (setelah diberi perlakuan)

Pengaruh Perlakuan $=\left(\mathrm{O}_{1}-\mathrm{O}_{2}\right)$

Penelitian ini dilaksanakan di

TK Aisyiyah 11 Palembang Pada

Tahun Ajaran 2019 yang berlokasi Jln. Jenderal Ahmad Yani 13 Ulu Seberang Ulu II, 13 Ulu, Kec. Plaju, Kota Palembang dan akan dilaksanakan pada bulan Oktober selama tiga minggu dengan dua kali pertemuan dalam satu minggu.

Tehnik pengumpulan data yang digunakan dalam penelitian ini dengan cara observasi dan dokumentasi. Observasi dilakukan untuk mengamati tingkah laku anak yang menunjukkan kreativitasnya. Dokumentasi digunakan sebagai media pengumpulan data dan sebagai bukti sebagai bukti bahwa penelitian ini memang benar-benar dilakukan.

Tehnik analisis data pada penelitian ini digunakan untuk membuktikan hipotesis penelitian, yaitu kegiatan permainan bola keranjang terhadap kemempuan motorik kasar anak kelompok B (5-6 tahun) di TK Aisyiyah 11
Palembang. Adapun teknik analisis data yang digunakan pada penelitian ini uji normalitas, uji homogenitas dan uji hipotesis. Dengan kriteria pengujian hipotesis, yaitu jika $t_{\text {hitung }}$ lebih besar dari tabel dengan taraf signifikan $(\alpha)=0,05$ maka dapat disimpulkan bahwa Ha diterima, sebaliknya jika thitung lebih kecil dari $\mathrm{t}_{\text {tabel }}$ maka Ha ditolak.

\section{PEMBAHASAN}

Pada tahap pelaksanaan pembelajaran peneliti hanya mengamati sedangkan yang melakukan kegiatan pembelajaran tetap guru kelas yang bersangkutan. Peneliti didampingi oleh guru kelas B2 dalam menjelaskan peratutan dan cara bermain bola keranjang.

Pada pertemuan pertama di laksanakan pada tanggal 2 Oktober 2019, anak diberikan tes awal atau pretest sebelum diberikan perlakuan. Kegiatan pretest adalah kegiatan yang berkaitan dengan motorik kasar yaitu kegiatan permainan sepak bola. Selanjutnya guru menyampaikan dan menjelaskan cara dalam permainan sepak bola. Dalam permainan ini anak dibagi menjadi dua tim yang beranggotakan 5 orang dalam satu tim. Dalam permainan ini anak hanya 
boleh menggunakan kaki dan menendang bola kedalam gawang lawan. Dalam permainan ini anak masih di bantu oleh guru.

\section{Pada pertemuan kedua} dilaksanakan pada tanggal 3 oktober 2019, pada pertemuan kedua ini anak mulai diberikan perlakuan yaitu kegiatan permainan bola keranjang, dalam kegiatan ini guru menyampaikan dan menjelaskan cara permainan bola keranjang. Dalam permainan ini anak dibagi menjadi dua tim yang beranggotakan 5 orang dalam satu tim yang bertujuan untuk memasukan bola kedalam keranjang lawan, dengan alat permainan yang sudah disiapkan yaitu bola dan keranjang yang telah disediakan.

\section{Pada pertemuan ketiga} dilaksanakan pada tanggal 7 oktober 2019, pada pertemuan ketiga ini anak masih diberi perlakuan yang sama yaitu kegiatan permainan bola keranjang, pada pertemuan ini guru masih menyampaikan dan menjelaskan cara permainan bola keranjang. Dalam permainan ini anak dibagi menjadi dua tim yang beranggotakan 5 orang dalam satu tim yang bertujuan untuk memasukan bola kedalam keranjang lawan, dengan alat yang sudah disiapkan yaitu bola dan keranjang yang telah disediakan.

Pada pertemuan keempat dilaksanakan pada tanggal 9 oktober 2019, peneliti masih memberikan perlakuan yang sama yaitu kegiatan permainan bola keranjang, pada pertemuan ini guru hanya mengingatkan tenantang permainan bola keranjang yang sebelumnya sudah dijelaskan dan anak diperintah untuk melakukan kegiatannya sendiri tapi masih dengan bantuan gurunya. Dalam permainan ini anak dibagi menjadi dua tim yang beranggotakan 5 orang dalam satu tim yang bertujuan untuk memasukan bola kedalam keranjang lawan, dengan alat yang sudah disiapkan yaitu bola dan keranjang yang telah disediakan.

Pertemuan kelima dilaksanakan pada tanggal 12 oktober 2019, peneliti masih memberikan perlakuan yang sama dengan yang sebelumnya yaitu kegiatan permainan bola keranjang, pada pertemuan ini guru mengingatkan kembali kegiatan permainan bola keranjang lalu anak 
diperintahkan

melakukan

kegiatannya sendiri tetapi masih dengan bantuan guru. Dalam permainan ini anak dibagi menjadi dua tim yang beranggotakan 5 orang dalam satu tim yang bertujuan untuk memasukan bola kedalam keranjang lawan, dengan alat yang sudah disiapkan yaitu bola dan keranjang yang telah disediakan.

Pertemuan terakhir di laksanakan pada tanggal 14 oktober yaitu pertemuan keenam penelitian memberikan kegiatan posttestuntuk mengetahui ada atau tidak pengaruh kegiatan permainan bola keranjang terhadap kemampuan motorik kasar anak setelah diberikan perlakuan permainan bola keranjang. Kegiatan posttest ini sama dengan kegiatan awal pretestyaitu kegiatan permainan sepak bola. Dalam kegiatan ini guru hanya mengawasi anak selama melakukan kegiatan permainan sepak bola

Dari hasil penelitian yang dilakukan terdapat pengaruh permainan bola keranjang terhadap kemampuan motorik kasar anak hal ini sejalan dengan teori yang dikemukakan olehSantrock dalam
(Kurniati, 2016) menjelaskan bahwa permainan (play) ialah suatu kegiatan yang menyenangkan yang dilaksanakan untuk kepentingan kegiatan itu sendiri. Permainan merupakan suatu aktivitas bermain yang didalamnya telah memiliki aturan yang jelas dan disepakati bersama. Dengan itu bahwa kegiatan yang paling menyenangkan bagi anak-anak ialah pada saat bermain.

$$
\text { Selanjutnya menurut }
$$

Atmasubrata (2012, hal.44) menjelaskan bahwa bola keranjang adalah olahraga bola berkelompok yang terdiri dari dua tim yang beranggotakan masing-masing lima orang dalam satu tim. Dalam permainan ini mereka bertanding saling mencetak poin dengan memasukan bola kedalam keranjang lawan.

Berdasarkan pendapat di atas dapat disimpulkan bahwa kegiatan permainan bola keranjang adalah suatu aktivitas yang sangat menyenangkan bagi anak, dalam permainan bola keranjang ini bertujuan untuk mencetak poin dengan melakukan kegiatan memasukan bola kedalam keranjang lawan. 


\section{KESIMPULAN DAN SARAN}

Berdasarkan penelitian yang telah di lakukan di TK Aisyiyah11

Palembang dapat ditarik kesimpulan bahwa kemampuan motorik kasar anak sebelum diberi perlakuan kegiatan permainan bola keranjang, kemampuam motorik kasar anak masih tergolong rendah. Hasil pretest dengan jumlah rata-rata yaitu 36,85 . Setelah dilakukan perlakuan dengan kegiatan permainan bola keranjang kemampuan motorik kasar anak semakin meningkat. Hasil posttest dengan jumlah rata-rata 64,8 .

Analisis perhitungan hasil pretest dan posttest menunjukan bahwa nilai $t_{\text {hitung }}>\mathrm{t}_{\text {tabel }}(6,20>$ 1,746) sehingga $H_{o}$ ditolak dan $H_{a}$ diterima. Maka dari hipotesis penelitian ini terdapat pengaruh permainan bola keranjang terhadap kemampuan motorik kasar anak kelompok B di TK Aisyiyah 11 Palembang.

Setelah melakukan penelitian ini disarankan kepada Guru dapat menggunakan kegiatan permainan bola keranjang untuk meningkatkan kemampuan motorik kasar anak, sehingga bisa membuat proses pembelajaran lebih menarik dan menyenagkan bagi anak. Bagi sekolah Diharapkan dapat menjadi acuan dan pertimbangan sekolah dalam menerapkan kegiatan yang tepat untuk meningkatkan kemampuan motorik kasar anak. Bagi peneliti selanjutnya Peneliti ini dapat menjadi referensi atau acuan dalam mengembangkan penelitian yang sejenis.

\section{DAFTAR PUSTAKA}

Atmasubrata, Ginanjar. 2012. Serba Tahu Dunia Olahraga. Surabaya: DAFA PUBLISHING

Cuacicha, Frida Citra. 2016. Pengaruh Bermain Lempar Tangkap Bola Terhadap Motorik Kasar Anak Kelompok B Di TK Pratiwi Sumberrejo Kotagajah Lampung Tengah. Universitas Lampung (Diakses Pada Tangal 01 Maret 2019, Pukul 12.01)

Desmita. $2015 . \quad$ Psikologi Perkembangan. Bandung: PT Remaja Rosdakarya

Evritasari, Amellia. 2019. Pengaruh Permainan Bola Basket Modifikasi Terhadap Kemampuan Motorik Kasar Anak Tk B.Universitas Negeri Surabaya ( Diakses Pada Tanggal 18 Juli 2019, Pikul 13.08)

Fadlillah, dkk. 2014. Edutainment Pendidikan Anak Usia Dini 
Menciptakan Pembelajaran Menarik, Kreatif, dan Menyenangkan. Jakarta: Prenada Media Group

Kurniati, Euis. 2016. Permainan Tradisional Dan Perannya Dalam Mengembangkan Keterampilan Sosial Anak. Jakarta: Prenada Media Group

Mursid. 2015. Belajar dan Pembelajaran PAUD. Bandung: PT Remaja Rosdakarya

Pratiwi, Yhana. dan Kristanto. 2014. Upaya Meningkatkan Kemampuan Motorik Kasar (Keseimbangan Tubuh) Anak Melalui Permainan Tradisional Engklek Di Kelompok B Tunas Rimba II Tahun Ajaran 2014/2016

Rahmani, Mikanda. 2014. Buku Super Lengkap Olahraga. Jakarta Timur: Dunia Cerdas

Rahyubi, Hari. 2016. Teori-Teori Belajar dan Aplikasi pembelajaran Motorik Deskripsi dan Tinjauan Kritis. Bandung: Nusa Media

Sudiro, Ahmad. 2018. Perilaku Organisasi. Jakarta: Bumi Aksara

Suryana, Dadan. 2018. Pendidikan Anak Usia Dini stimulasi dan Aspek Perkembangan Anak. Jakarta: Prenada Media Group

Susanto, Ahmad. 2017. Pendidikan Anak Usia Dini (Konsep dan Teori). Jakarta: PT Bumi Aksara
Sutanto, Teguh. 2016. Buku Pintar Olahraga. Yogyakarta: Pustaka Baru Press

Suyadi dan Ulfa, Maulidya. 2015. $\begin{array}{lcc}\text { Konsep } & \text { Dasar } & \text { PAUD. } \\ \text { Bandung: } & \text { PT } & \text { Remaja } \\ \text { Rosdakarya } & & \end{array}$

Wati, Rahmah. 2012. Pengaruh Permainan Modifikasi Bola Basket Terhadap Kemampuan Motorik Kasar Anak Di Kelompok B2 TK AlKhairaat III Palu. Universitas Tadulako (Diakses Pada Tanggal 01 Maret 2019, Pikul 11.55) 